\title{
The Effect of Recreational Activities on the Self-esteem and Loneliness Level of the Prisoners as an Alternative Education ${ }^{\text {i }}$
}

\author{
Zekiye Basaran \\ School of Physical Education and Sports, Kocaeli University, Turkey
}

Copyright $(2016$ by authors, all rights reserved. Authors agree that this article remains permanently open access under the terms of the Creative Commons Attribution License 4.0 International License

\begin{abstract}
Aim: The purpose of this research is to investigate the effect of recreational activities on the self-esteem and loneliness level of prisoners as an alternative education. Method: The sample of this research consisted of 23 female prisoners who were randomly selected in Kandira prison and detention house. As preliminary and final tests, these prisoners were given a personal information form, self-esteem and UCLA Loneliness Scale. The program lasted one and a half hours a day, two days a week and twelve weeks. The activities were composed of music, dancing, meditation, sports activities, videos and entertaining competitions. The data were analyzed with Wilcoxon and correlation tests in SPSS 18 package program $(\mathrm{p}<0.05)$. The findings: The prisoners were aged between 20 and 59 and they were in prison for less than one year and for 10 years. A statistically positive and significant connection was determined between loneliness preliminary test and final test scores $(p=0.001)$ in the group. A statistically negative connection was calculated in the correlation analysis that was performed between self-esteem level in preliminary and final tests $(0.002)$ and loneliness level in preliminary and final tests (0.012). Conclusion: Recreational activities were specified to have positive effect on increasing the self-esteem level and decreasing loneliness level of the prisoners.
\end{abstract}

Keywords Recreational Activities, Self-esteem, Loneliness, Prisoner

\section{Introduction}

Our living conditions have an effect on our self-esteem. Coopersmith [8] defines the self-esteem notion as individual's self-perception level of being adequate, important, successful and valuable. According to Rosenberg [35], the individuals having a high level of self-esteem feel themselves valuable and esteemed. This helps them to be satisfied with their lives and therefore they become more productive [20]. On the other hand, the individuals having a low level of self-esteem are not satisfied with themselves [35]. They generally have a negative approach towards life and future [20]. They have such problems as a lack of self-confidence, anxiety, lack of communication or adaptation and their psychological health is worsening day by day $[17 ; 26]$.

The connection between the self-esteem level and with a lot of issues like age, gender, friends, family structure, economic status, social status, the way they behave, and how they spend their leisure time was analyzed in the previously conducted researches. The self-esteem scores were found to be higher in people who are supported by their families or friends, whose life conditions, social and financial life is better, who have a positive attitude towards life and who spend their leisure time with activities [43;39;4;13;29]. The self-esteem level was observed to be low in people who are in the reverse and who have alcohol addiction, personality disorder [24]; people who were diagnosed with psychiatry [2]; the lower the self-esteem level is, the higher the loneliness level becomes.

There are studies in the literature which illustrate that self-esteem and loneliness affect each other reversely. In the studies in which Karahan et al. [26], Guloglu\&Karairmak [17], Koçak [28], and Softa et al. [38] performed with university students and teenagers so as to determine the connection between the self-esteem and loneliness; it was found that if the self-esteem level was lower, the loneliness level was higher. As the self-esteem level increased, the loneliness level decreased.

According to Young [45], the loneliness considered as the lack of communication and feeling empty has such symptoms as lack of satisfactory in social relations, and the symptoms of psychological stress accompanied by this real or fictional emptiness. It is a more qualitative matter rather than a quantity matter and it is observed in the society commonly. [11]. Hagerty and Williams [19] have stated that loneliness emerges because of the inability to belong and 
decreasing level of social support. Loneliness can be experienced in two different ways. Emotional isolation is a kind of emptiness in the person's inner world. However, social isolation is a feeling that a person has when s/he feels excluded from the society [12]. Loneliness observed to be related to many factors such as depression, desolation, hopelessness, low level of self-esteem, low level of life satisfaction, adaptation difficulty, suicidal, violence, alcoholism, incompetency, shyness, state-trait and social anxiety, lack of social relations and alienation $[36 ; 17 ; 30]$ is a common, gloomy and enervating problem that affects the individual's whole life [27].

One of the places where the loneliness is deeply felt is the detention house. The prisoners here try to follow the rules and get on with the people in there. On the other hand, they miss their home and beloved ones. They feel distressful, uneasy and lonely. One of the solutions that can relieve them and minimize their loneliness is recreational activities [32;23;41]. Recreation, one of the leisure time activities, makes people busy with sports, cultural and artistic activities. It makes them happy and integrated into social life. In short, it makes people have nice time.

Recreation is a part of education provided in schools. Education is a process in which individuals make the desired changes in their lives. It is offered in many different fields such as social, institutional, non-formal, formal and special education. One type of education is alternative education. It is the application of the program prepared accordingly on certain individuals or groups. As an alternative education, recreation has numerous benefits such as following the rules, building up a strong communication, improving oneself and the skills, the ability to work in groups, getting information and spending their leisure time more effectively. For this reason, such an education can be applied to different types of groups like the street urchins, problematic members in the society, or elderly in the nursing homes. One of the groups on which this education can be useful is the prisoners in jail. So, the purpose of this study is to examine the effect of recreational activities on the self-esteem and loneliness level of the prisoners as an alternative education.

\section{Material and Methods}

Research group: the sample of this research consisted of 23 volunteering convicted females in Kandira Open Detention House and Prison.

Sosyo-Demographic Information of the Female Convicts in the Research

\begin{tabular}{|c|c|c|c|}
\hline Variables & Sub-categories & Frequency (f) & Percent (\%) \\
\hline \multirow{5}{*}{ Age } & $20-29$ & 8 & 34.8 \\
\hline & $30-39$ & 8 & 34.8 \\
\hline & $40-49$ & 5 & 21.7 \\
\hline & $50-59$ & 2 & 8.7 \\
\hline & Total & 23 & 100 \\
\hline \multirow{4}{*}{ Educational background } & Elementary & 13 & 56.5 \\
\hline & High school & 8 & 34.8 \\
\hline & University & 2 & 8.7 \\
\hline & Total & 23 & 100 \\
\hline \multirow{4}{*}{ Marital Status } & Single & 10 & 43.5 \\
\hline & Married & 7 & 30.4 \\
\hline & Divorced & 6 & 26.1 \\
\hline & Total & 23 & 100 \\
\hline \multirow{3}{*}{ Nationality } & Turkey & 22 & 95.7 \\
\hline & Foreign National (Alien) & 1 & 4.3 \\
\hline & Total & 23 & 100 \\
\hline \multirow{4}{*}{ Length of sentence } & $0-5$ & 18 & 78.3 \\
\hline & $6-10$ & 4 & 17.4 \\
\hline & 11 and over & 1 & 4.3 \\
\hline & Total & 23 & 100 \\
\hline \multirow{4}{*}{ Visitors } & No Visitors & 7 & 30.4 \\
\hline & My Family & 13 & 56.5 \\
\hline & My Friends & 3 & 13 \\
\hline & Total & 23 & 100 \\
\hline
\end{tabular}


The table illustrates that 34.8 percent of the female convicts in the research were 20 and 29 years old and 30 and 39 years old; 21.7 percent of them were between 40 and 49; 8.7 percent was between 50 and 59 . As for their educational background, 56.5 percent of them graduated from Elementary School; 34.8 percent of them graduated from High school; and 8.7 percent of them were the graduates of university. Another finding was about their marital status; 43.5 percent of them were single; 20.4 percent was married and 26.1 percent was divorced. When it came to their nationality, we saw that 95.7 percent of the convicts' nationality was Turkey, and only 4.3 percent was foreign nationalities. The finding concerning their length of sentence was as follows; 78.3 percent was sentenced to 0 and 5 years;
17.4 percent was sentenced to 6 and 10 years; 4.3 percent was sentenced to 11 years and more. It was also observed in Table 6 that 30.4 percent of these convicts had no visitors at all. However, 56.5 of them were visited by their family members. The other 13 percent was visited by their friends.

The group was given different activities one and a half hours a day and two days a week. These activities were performed between April and June 2014, and lasted for 12 weeks. The selection of activities was made by taking into account of the conditions in prison. These were target-oriented activities that complemented each other. They were relaxation-friendly activities directed to earning success and trust and they strengthened communication and cohesion.

The Recreational Activity Program

\begin{tabular}{|c|c|c|c|c|}
\hline DATE & DAY & HOUR & ACTIVITY & CONTENT \\
\hline 08.04 .2014 & Tuesday & $14: 00-15: 30$ & Silent Movie Game & Tell with sign language \\
\hline 10.04 .2014 & Thursday & $14: 00-15: 30$ & Bocce & Play among groups at the yard \\
\hline 15.04 .2014 & Tuesday & $14: 00-15: 30$ & Turkish Folk Music & $\begin{array}{l}\text { The concert of university's music } \\
\text { group }\end{array}$ \\
\hline 17.04 .2014 & Thursday & $14: 00-15: 30$ & Zumba & Dance with music \\
\hline 22.04 .2014 & Tuesday & $14: 00-15: 30$ & Pop Music & Concert of the music group \\
\hline 24.04 .2014 & Thursday & $14: 00-15: 30$ & Belly Dance & Dance with music \\
\hline 29.04 .2014 & Tuesday & $14: 00-15: 30$ & Volleyball & Play at the yard \\
\hline 01.05 .2014 & Thursday & $14: 00-15: 30$ & Fun Games & Chair \& sack play \\
\hline 06.05 .2014 & Tuesday & $14: 00-15: 30$ & Aerobic & With music \\
\hline 08.05 .2014 & Thursday & $14: 00-15: 30$ & Karaoke & Sing with music \\
\hline 13.05 .2014 & Tuesday & $14: 00-15: 30$ & Turkish Folk Dance & Halay \& Horon \\
\hline 15.05 .2014 & Thursday & $14: 00-15: 30$ & Beauty Contest & Among them \\
\hline 20.05 .2014 & Tuesday & $14: 00-15: 30$ & Frisbee & Play at the yard \\
\hline 22.05 .2014 & Thursday & $14: 00-15: 30$ & Badminton & Play at the yard \\
\hline 27.05 .2014 & Tuesday & 14:00-15:30 & Movie & Comedy \\
\hline 29.05 .2014 & Thursday & $14: 00-15: 30$ & Gypsy Dance & Dance together \\
\hline 03.06 .2014 & Tuesday & $14: 00-15: 30$ & Making Small Sculptures with Dough & Different animals \\
\hline 05.06 .2014 & Thursday & $14: 00-15: 30$ & Turkish Art Music & The music group's concert \\
\hline 10.06 .2014 & Tuesday & $14: 00-15: 30$ & Slide Show With Photographs & With music \\
\hline 12.06 .2014 & Thursday & $14: 00-15: 30$ & Orienteering & Inside the hall and in the yard \\
\hline 17.06 .2014 & Tuesday & $14: 00-15: 30$ & Singing Competition & $\begin{array}{l}\text { Begin with last words between two } \\
\text { groups }\end{array}$ \\
\hline 19.06.2014 & Thursday & 14:00-15:30 & Salsa & Dance with music \\
\hline 24.06 .2014 & Tuesday & 14:00-15:30 & Funny Videos Display & Various videos \\
\hline 26.06 .2014 & Thursday & $14: 00-15: 30$ & Aerobic $\left(60^{\prime}\right)$ \& Meditation (30’) & With music \& words \\
\hline
\end{tabular}


Data Collection Tool: Personal information forms including socio-demographic features, Coopersmith Self-esteem Inventory and UCLA Loneliness Inventory were used as the data collection tool.

The Scale of Socio-demographic Features: this scale was prepared by the researcher and it contained the questions about the participants' ages, their educational background, marital status, nationalities, the length of their sentence and their visitors.

Coopersmith Self Esteem Inventory (CSEI): It was developed by Coopersmith in 1967 so as to evaluate the person's social, personal, academic, and familial opinions. He calculated the reliability coefficient of the test-retest in the inventory as 0.88 (every 5 weeks) and 0.70 (every 3 years). Coopersmith also specified the Kuder-Richardson reliability coefficient as 0.91 for the female students and 0.80 for the male students. It has been revised a few times since it was developed. These are School Form, School Short Form, and Adult Form. This scale is composed of 58 items. A total score related to self-esteem and five different sub-scales can be obtained from the scale. These are the items of a) general self-esteem, b) social self-esteem, c) school-academic self-esteem, d) self-esteem related to family and home, e) lie. After excluding 8 items of lie, remaining 50 items are multiplied with 2 and evaluation is performed out of 100 . School Short Form consists of the first 25 questions of the School Form and it does not have a lie scale. It has been applied to children. Total scores are taken into account. Turkish validity and reliability has been carried out by Turan and Tufan (1987, r=0.76), Ozogul (1988 r=0.77), Gucray (1989 r=0.70 and 0.83), and Piskin (1996 r=0.76) [29]. Those saying 'No' for a negative statement and 'Yes' for the positive one are given one point for each statement. All points are added and they are multiplied with 4 so as to make the assessment out of 100 . Thus, the score obtained after all these steps shows the person's self-esteem level. If the score is high, it means that the level of self-esteem is high; if it is low, the self-esteem level is low [21]. Coopersmith's (1991) short form (CSEI), Turkish validity and reliability conducted by Piskin (1996) and applied on adults in the studies of Dincer \& Oztunc [10] and Mutlu \& Duyan [31] was used in this study. The reliability coefficient was found to be $\mathrm{r}=0.76$ $(\mathrm{p}<0.05)$.

UCLA LS Loneliness Scale: University of California Los Angeles Loneliness Scale was developed by Russel, Peplau and Ferguson [37] so as to determine the loneliness level of the person. Later, all the statements were revised one by one by Russel, Peplau and Cutrona [36]. Then, it was changed into half negative and half positive. The scale is composed of 20 items. It is a 4-point Likert scale and scoring has been prepared as 1- Never, 2-Rarely, 3-Sometimes, 4-Frequently.
Total score the individual gets from the scale is found by summing up the scores obtained from the plain and reverse items. The highest score that can be obtained from the scale is 80 and the lowest score is 20. A score between 20 and 40 indicates low level, 41-60 indicates medium level and 61-80 indicates high level of loneliness. The higher the score is, the higher level of loneliness is [11]. Russell et al. have stated that Cronbach Alpha internal consistency coefficient of the original scale is 0.94 and re-test correlation coefficient is .73 . The scale was adapted into Turkish by Demir [9]. Demir has found that Cronbach Alpha internal consistency coefficient of the scale is 0.96 and re-test correlation coefficient performed every five weeks was found to be 0.94 . Cronbach's Alpha coefficient of the scale was calculated as ( $\alpha$ ) .817 in this study.

Collecting the data: data were obtained via the scales. The questionnaires were performed as pre-tests on the first day in the meeting before the program and as post-test on the final day after the last activity (meditation) to those who were in the hall at the same time. The processes took about 30 minutes. The Ministry of Justice was requested for allowance at the preparation period and Kocaeli University Ethics Council was asked for approval at the end of the program. The work permit by the Ministry of Justice: Date: 26.03.2014 Issue: 57292265-204.06.03-591/51477 Ethics Committee of Kocaeli University Number: 15.04.2014 verdict number: 9/4 Project No: KOU KAEK 2014/126

Analysis of the data: data were analyzed with descriptive statistics, Wilcoxon and Correlation in the SPSS 18 package program. The significance level was taken as 0.05 .

\section{Results}

In this part, the findings concerning the results of this research were illustrated in Tables.

Table 1. Self-esteem Wilcoxon test results of the research group for pre-test and post-test

\begin{tabular}{|c|c|c|c|c|}
\hline Self-Esteem & N & Mean & $\begin{array}{c}\text { Std. Deviation } \\
\text { (SD) }\end{array}$ & P \\
\hline Self-Esteem Pre-Test & 23 & 64.17 & 16.20 & \\
\hline Self-Esteem Post-Test & 23 & 66.78 & 14.35 & .314 \\
\hline
\end{tabular}

$\mathrm{p}<0.05$

According to Table 1, after the comparison of self-esteem pre-test and post-test values of the convicts in the research group, no statistically significant connection (.314) was found $(p<0.05)$. However, statistical increase was observed between the averages of post-test $(66.78 \pm 14.35)$ and pre-test

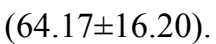


Table 2. Statements in the Self-Esteem Inventory of the research group pre-test and post-test of Wilcoxon test results.

\begin{tabular}{|c|c|c|c|c|c|c|c|}
\hline \multirow{2}{*}{ Self-Esteem Questions/Statements } & \multirow{2}{*}{$\mathbf{N}$} & \multicolumn{3}{|c|}{ Self-Esteem Test } & \multirow{2}{*}{$Z$} \\
\cline { 3 - 6 } & & \multicolumn{2}{|c|}{ Zre-Test } & \multicolumn{2}{|c|}{ Post-test } \\
\cline { 3 - 6 } & & Mean & SD & Mean & SD & \\
\hline I find it difficult to talk in front of others. & 23 & 1.63 & 0.49 & 1.86 & 0.35 & -2.236 & .025 \\
\hline I would like to change many things in me if I could. & 23 & 1.13 & 0.35 & 1.31 & 0.47 & -2.000 & .046 \\
\hline I cannot get used to new things easily. & 23 & 1.27 & 0.45 & 1.59 & 0.50 & -2.111 & .035 \\
\hline I often dream of being someone else & 23 & 1.63 & 0.49 & 1.86 & 0.35 & -2.236 & .025 \\
\hline
\end{tabular}

$\mathrm{p}<0.05$

Table 2 illustrates that a significant difference $(\mathrm{p}=.05)$ was found between the pre-test and post-test of the answers by the convicts in the research group to the following statements: 'I find it difficult to talk in front of others" (.025);' I would like to change many things in me if I could" (.046); "I cannot get used to new things easily" (.035); "I often dream of being someone else" (.025).

Table 3. UCLA-Loneliness of the research group pre-test and post-test of Wilcoxon test results.

\begin{tabular}{|c|c|c|c|c|}
\hline UCLA-LS Loneliness & N & Mean & Std. Deviation (SD) & P \\
\hline Loneliness Pre-Test & 23 & 44.78 & 8.83 & \\
\hline Loneliness Post-Test & 23 & 37.96 & 7.69 & .001 \\
\hline
\end{tabular}

$\mathrm{p}<0.05$

According to Table 3, a statistically significant connection (.001) was found between the pre-test and post-test comparison in loneliness level of convicts.

Table 4. Statements in the UCLA-Loneliness Inventory of the research group pre-test and post-test of Wilcoxon test results.

\begin{tabular}{|c|c|c|c|c|c|c|c|}
\hline \multirow{2}{*}{ UCLA-LS Loneliness Questions/Statements } & \multirow{2}{*}{$\mathbf{N}$} & \multicolumn{3}{|c|}{ Loneliness Test } & \multirow{2}{*}{ Z } & \multirow{2}{*}{ P } \\
\cline { 3 - 7 } & & \multicolumn{2}{|c|}{ Pre-Test } & \multicolumn{2}{|c|}{ Post-Test } & \\
\cline { 3 - 7 } & & Mean & SD & Mean & SD & & \\
\hline I have no friends. & 23 & 2.13 & 1.06 & 1.61 & 1.08 & -2.292 & .022 \\
\hline I have no one to consult. & 23 & 2.22 & 1.28 & 1.70 & 1.02 & -1.968 & .049 \\
\hline I do not feel as if I am alone. & 23 & 2.43 & 1.20 & 3.09 & 1.08 & -2.13 & .033 \\
\hline I am unhappy for being so introvert. & 23 & 2.48 & 1.12 & 1.65 & 0.83 & -2.8 & .005 \\
\hline I have people around me but they are not with me. & 23 & 2.57 & 1.27 & 1.83 & 1.07 & -2.43 & .015 \\
\hline
\end{tabular}

$\mathrm{p}<0.05$

When we look at the Table 4, we see that there is a significant connection between the pre-test and post-test of the answers given by the convicts in the research group for the statements: "I have no friends" (.022); "I have no one to consult" (.049); 'I do not feel as if I am alone" (.033); 'I am unhappy for being so introvert"' (.005); and "I have people around me but they are not with me" $(.015)$.

Table 5. The Correlation Analysis of the loneliness and self-esteem tests in the research group

\begin{tabular}{|c|c|c|c|c|c|}
\hline Inventories & N & Mean & SD & r & p \\
\hline Self-Esteem Pre-Test & 23 & 16.04 & 4.05 & & \\
\hline UCLA-LS Loneliness Pre-Test & 23 & 44.78 & 8.84 & $-.612 *$ & .002 \\
\hline Self-Esteem Post-Test & 23 & 16.7 & 3.6 & & \\
\hline UCLA-LS Loneliness Post-Test & 23 & 37.96 & 7.7 & -.514 & .012 \\
\hline
\end{tabular}

*p $<0.01 ; \mathrm{p}<0.05$

At the end of this correlation analysis, a statistically negative connection was found between the pre-tests $(\mathrm{r}=-.612 \mathrm{p}=.002)$ and post-tests $(\mathrm{r}=-.514 \mathrm{p}=.012)$ of both the self-esteem and the loneliness level of the convicts in the research group. 


\section{Discussion}

How useful can recreation activities be for the convicts in a place which is dominated by longings and regrets? This research was led by this question and it was aimed to determine the effect of recreational sports and cultural activities on the loneliness and self-esteem level of the convicted women as an alternative education.

Women who participated in this research are aged between 20 and 59. 70 percent of women in the group are aged between 20 and 39. Regarding the educational background of the group, 54 percent is elementary school graduates, 39 percent is high school and 7 percent is postgraduates. As for their marital status, the rate of the single ones is higher in the group. Most of them have Turkish Nationality; yet, 4.3 percent of the women have foreign nationalities. In the studies conducted by Celik [6], Icli \& Ogun [22], Gurtuna [18], and Coban \& Akgun [7]; 55 percent of the convicted women were elementary school graduates. The rate of the married and single ones was approximately equal. They were aged between 20 and 40 $(69 \%)$. The women's length of sentence in this research varies from less than 1 year to 10 years (95\%). 30.4 percent of women in the group did not have any visitors. This rate was 67 percent in Coban \& Akgun's research [7].

The application of exercise programs in prisons will encourage them and it is good for their health. There are experimental data that availably that support this condition [3]. Three basic purposes of prison-based sports activities were determined in the research by Gallant et al. [14]; the health and wellness of the convicts; the rehabilitation of the convicts and the management of the convicts. It was clearly understood that sports and recreation programs had a positive effect on the health of the convicts and their behavior. However, the rehabilitation via sports was left unclear. Bensimon et al. [5] have stated that the comforting music decreases anxiety and anger level of the convicts.

When the effect of activities on the self-esteem level was examined, the following results were observed: there was an increase between the self-esteem pre-tests scores $(64.17 \pm$ $16.20)$ and post-test scores $(66.78 \pm 14.35)$ in the research group, but this was not statistically significant (.314) (Table 1). While Whitehead, Corbin, \& Fox [43] have stated that the physical activities and PE programs can promote the self-esteem if applied correctly, Tremblay et al. [39] have found a positive connection between the sports activities and the self-esteem level. Bayazit [4] has also determined the positive effect of the recreational activities on the self-esteem level of teenage women. There are studies indicating that recreational activities decrease social phobia and promote the self-esteem level [25]. In contrast, Walters $\&$ Martin [42] have declared that aerobics exercises have no effect on increasing the self-esteem level; similarly, Acar [1] has uttered that even if teamwork has an increasing effect on the self-esteem level of the convicted children compared to the ones in the control group, this increase is not statistically significant. These results support ours. When the self-esteem scores are examined according to the questions in the scale, the findings can be summarized as below: a statistically significant connection $(\mathrm{p}<0.05)$ has been found between pre-tests and post-tests of the answers of women in the research group to the statements: "I find it difficult to talk in front of others." (.025), "I would like to change many things on me if I could" (.046), "I cannot get used to new things easily" (.035), "I often dream of being someone else" (.025) (Table 2). In the group, even though there is not a significant connection in total scores, statistically significant differences have been found when each statement is examined one by one. This result illustrates that recreational activities have a promoting effect on the self-esteem level of the convicts even in prison conditions.

According to the Law No. 4301 and Date 16/08/1997, Prisons and Penal Institutions have such a mission to help the prisoners and convicted people in prisons to get an occupation in Turkey. So there are productions in more than 40 work-branches [44]. Kandira Open Detention House and Prison, where this research has been carried out, is the one that has quite a big garden and a closed area. It offers the convicts some courses to find jobs, religious and recreational facilities. The convicts are free to choose the one they like.

Bringing these activities into the prison life is considered as an excellent attempt to make them come together and spend their leisure time by doing exercises so that they can forget their loneliness [15]. In this research, the pre-test scores of the research group being at an average level $(44.78 \pm 8.83)$ have been found to be lower in the post-test $(37.96 \pm 7.69)$ and a statistically significant difference has been found between the scores of the two test $(p=.001)$ (Table 3 ). This result illustrates that recreational activities have a decreasing effect on the level of loneliness. The loneliness inventory has been examined with respect to the questions, as well (Table 4). A statistically positive difference $(p<0.05)$ has been found between pre-tests and post-tests of the answers by the convicts in the experimental group to the statements: "I have no friends" (.022); "I do not have anyone to consult" (.049); "I do not feel myself as if I am alone" (.033); "I am unhappy because of being so introvert" (.005); "I have people around but they are not with me" (.015). These results illustrate that their loneliness level has decreased and they have become more socialized. There are studies supporting that the activities are beneficial to decrease loneliness. Ozcelik et al. [32] have found a significant difference between the loneliness level of male students and doing sports. Kalkan, et al. [23] have declared that swimming has decreased their loneliness level. In the research by Uzuner \& Karagun [41], loneliness level scores of people doing sports as recreation have been found to be quite low.

Correlation analysis has been performed in this research so as to determine whether there is a connection between self-esteem level of the convicts in the group and their loneliness level. At the end of this analysis, statistically 
significant connections have been found to be negative between the pre-tests $(\mathrm{r}=-.612 ; \mathrm{p}=.002 \mathrm{p}<0.01)$ and post-tests $(\mathrm{r}=-.514 ; \mathrm{p}=.012 \mathrm{p}<0.05)$ of the self-esteem level and loneliness level (Table 5). In their research, Guloglu \& Karairmak [17] and Softa et al. [38] have stated that there is a statistically significant connection between the self-esteem and loneliness level. According to this, the higher the self-esteem level is, the lower the loneliness level becomes. Karahan et al. [26] have reversed this definition in a different way and have said that the higher the loneliness level is, the lower the self-esteem level becomes. These three studies comply with our research and the results illustrate that as an alternative education, those recreational activities have useful effects even under the conditions in prisons.

\section{Conclusions}

In conclusion, 24 different recreational activities applied for 12 weeks have been observed to have an increasing positive effect on the convicts' self-esteem level and decreasing the negative effect on their loneliness level. This effect may help them socialize, feel relieved, have an optimistic attitude towards life, and have a good communication with people around them. It may contribute to their psychological health and decrease their inner fight with themselves. These positive changes may affect their behaviors, therefore there can be a peaceful environment in the prison. Furthermore, it may ease the management's work. In addition, it may have contributions to their normal life after their sentence is over.

Similar researches are suggested to be performed with more participants and in different location. In addition, such an alternative education is also advised to be applied to children who don't like school, teenagers experiencing some problems due to the adolescence, people with social phobia, disabled members of the society, young people who hold the risk of committing crimes and street urchins.

\section{Acknowledgements}

I extend thanks to the authorities in the Ministry of Justice, the management and staff of Kandira Open Prison, convicts who participated in our research and all participants who supported this research, Seher Busra Tanıl, Mine Gül and Gülbin Eskiyecek for their support.

\section{REFERENCES}

[1] Acar, B.Y. (2009). The Effect of group work on the level of self-esteem, emphatic skills and social relationships of convicted young sexual offenders. Toplum ve Sosyal Hizmet Dergisi, Nisan, 20(1): 33-46. Retrieved from; http://www.acarindex.com/dosyalar/makale/acarindex-14239 31286.pdf
[2] Alkin, T., Baykara, A. (1992). Hasta ve sağlıklı ergenlerde benlik saygısı. Dokuz Eylül University Tıp Fakültesi Dergisi, 1992; 6(1): 14-20. Retrieved from; file://C:/Documents\%2 0and\%20Settings/Z/Belgelerim/Downloads/1120.pdf

[3] Ambrose, M. \& Rosky, J.W. (2013). Prisoners' Round: Examining the literature on recreation and exercise in correctional facilities. International Journal of Criminology and Sociology 2:362-370. Retrieved from; https://www.cohpa.ucf.edu/media/823571/rosky_000.pdf

[4] Bayazit, B. (2014). The Effect of recreational activities on self-esteem development of girls in adolescence. Educational Research And Reviews, 9 (20), 920-924 DOI: 10.5897/ERR2014.1860

[5] Bensimon, M., Einat, T., Gilboa, A. (2015). The Impact of relaxing music on prisoners' levels of anxiety and anger. International Journal of Offender Therapy and Comparative Criminology , 59(4): 406-423 DOI: 10.1177/0306624X1351 1587

[6] Celik, H. (2008). A Sociological analysis of women criminals in the Denizli open prison, Unpublished Master Of Science Thesis, Middle East Technical University, Ankara, Turkey

[7] Coban, A.I., Akgun, R. (2011). Figuring out of psycho-social conditions and determination the social supports of women who stays in Ankara closed penal Institution for Women. Toplum ve Sosyal Hizmet, 22 (2): 63-78. Retrieved from; http://www.tsh.hacettepe.edu.tr/Arsiv/20112.pdf

[8] Coopersmith, S. (1967). The Antecedents of Self-Esteem. San Francisco: W.H. Freeman. Retrieved;http://fetzer.org/sit es/default/files/images/stories/pdf/selfmeasures/SelfMeasure $\mathrm{s}$ for Self-Esteem COOPERSMITH SELF-ESTEEM INV ENTÖRY.pdf

[9] Demir, A. (1989). UCLA yalnızlık ölçeğinin geçerliği ve güvenirliği. (The Reliability and validity of the UCLA Loneliness Scale) Türk Psikoloji Dergisi (Turkish Psychology Journal), 7(23): 14-18 Retrieved from; http://www.turkpsikolojidergisi.com/PDF/TPD/23/01.pdf

[10] Dincer, F.; Oztunc, G. (2009). Self-Esteem and assertiveness levels of nursing and midwifery students. Hacettepe University, Faculty of Health Sciences Nursing Journal, $22-33$

[11] Duy, B. (2003). Bilişsel-davranışçı yaklaşıma dayalı grupla psikolojik danışmanın yalnızlık ve fonksiyonel olmayan tutumlar üzerine etkisi (Effect on loneliness and dysfunctional attitudes of the group counseling based on cognitive-behavioral approach). (Unpublished doctoral dissertation), Ankara University, Institute of Educational Sciences, Department of Educational Sciences (Guidance and Psychological Counselling Program), Ankara, Turkey

[12] Erozkan, A. (2009). The Predictors of loneliness in adolescents. Elementary Education Online, 8(3): 809-819. http://ilkogretim-online.org.tr (Retrieved in August 29, 2015).

[13] Ersan, E., Dogan, O., E., Dogan, S. (2009). The Relationship between Self-esteem Levels and some sociodemographic characteristics of the students of college of physical education and sports. Klinik Psikiyatri, 12:35-42

[14] Gallant, D., Sherry, E., Nicholson, M. (2014). Recreation or rehabilitation? Managing sport for development programs 
with prison populations. Sport Management Review, 18(1) 45-56. Retrieved; http://www.antoniocasella.eu/archica/Gall ant_2014.pdf

[15] González-Aja, T., Viuda-Serrano, A. (2010). Concepción Arenal and her vision of women's physical education in prison in Spain during the nineteenth century. International Review on Sport and Violence, 2:25-41. Retrieved from; https://www.researchgate.net/profile/Alex_Viuda-Serrano/pu blication/233763390 Concepcin Arenal and her vision of women's physical education in prison in Spain during $\mathrm{t}$

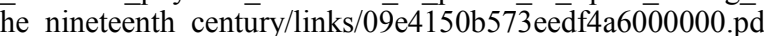
f

[16] Gucray, S. (1989). Some factors which are affecting self-esteem of the children who are 9-11 ages and stay with their families and in foundling hospital. Unpublished doctoral dissertation, Hacettepe University, Ankara, Turkey.

[17] Guloglu, B., Karairmak, Ö. (2010). Self-Esteem and resilience as the predictors of loneliness among university students. Ege Eğitim Dergisi (Ege university journal), (11)2:73-88. Retrieved from;

http://www.egitim.ege.edu.tr/efdergi/issues/2010-11-2/201011-2.pdf

[18] Gurtuna, O. (2009). Cezaevinde kadın olmak ve cezaevinin kadın bakış açısıyla sosyolojik değerlendirmesi: Ankara Sincan kadın kapalı cezaevi örneği. (Being a woman in prison and assessment of the prison with women' look the angle). (Unpublished Master's Thesis) Ankara University, Ankara, Turkey

[19] Hagerty, B.M. \& Williams, R.A. (1999). The effects of sense of belonging, social support, conflict and loneliness on depression. Nursing Research, 48, 215-219. (Retrieved from); http://dx.doi.org/10.1097/00006199-199907000-00004

[20] Hicdurmaz, D., OZ, F. (2011). Benliğin bilişsel yaklaşımla güçlendirilmesi (Derleme). (Empowerment of self via cognitive approach), Sağlık Bilimleri Fakültesi Hemşirelik Dergisi, 68-78.

http://www.hacettepehemsirelikdergisi.org/pdf/pdf_HHD_12 5.pdf

[21] http://www.mebk12.meb.gov.tr/.../18012106_coopersmithoz saygienvanteri. (Retrieved May 09, 2014)

[22] Icli, T., Ogun, A. (1988). Sosyal değișme sürecinde kadın suçluluğu (Woman guilty in social change process), Hacettepe University Edebiyat Fakültesi Dergisi, 2: 17-32. Retrieved from; http://www.edebiyatdergisi.hacettepe.edu.tr/ index.php/EFD/article/view/324/200

[23] Kalkan, M., Tekat, A., Koc, H.E., Sozen, H. (2010). yüzme eğitiminin çocukların yalnızlık düzeylerine etkisi: deneysel bir çalışma (Effects on children's loneliness levels of swimming training). Beden Eğitimi ve Spor Bilimleri Dergisi. 5 (1): 1-6. Retrieved from; file://C:/Documents\%20 and\%20Settings/Z/Belgelerim/Downloads/7-7-PB\%20(1).pd f

[24] Karaer, Ş., Kugu, N., Dogan, O., Akyuz, G. (2004). Sivas il merkezinde alkol kötüye kullanımı ve bağımlılığ olanlarda kişilik bozuklukları, benlik saygısı ve aile işlevleri (Personality disorders, Self Esteem and family functioning at the alcohol addicted). (3P) Psikiyatri Psikoloji Psikofarmakoloji. Dergisi, 12(1):11-20, Retrieved from; http://psikiyatridizini.net/viewarticle.aspx?articleid $=1842$

[25] Karagun, E., Yildı, M., Basaran, Z., Caglayan, C. (2010).
Sosyal fobi özellikleri gösteren üniversite öğrencilerinde rekreatif aktivitelerin fobik tutumlar üzerine etkisinin araştırılması (The effect of recreational activities on phobic attitudes of the university students with social phobia: a comparative study). Anatolian Journal of Psychiatry,139-144. Retrieved;

http://akademikpersonel.kocaeli.edu.tr/ekaragun/sci/ekaragu n26.04.2010_19.53.20sci.pdf

[26] Karahan, F.T., Sardogan, M.E., Gar, A.H., Ersanli, E., Kaya, S.N., Kumcagiz, H. (2004). The relationships between the levels of loneliness and levels of self-esteem of university students. Ondokuz Mayıs University Eğitim Fakültesi Dergisi, 18: 27-39. Retrieved from; http://www.arastirmax.c om/system/files/1066/uvt 46018.pdf

[27] Killeen, C. (1998). Loneliness: an epidemic in modern society. Journal of Advanced Nursing, 28(4): 762-770.

[28] Kocak, E. (2008). An examination of self-esteem, trait anger and types of expressions as the predictor of loneliness among adolescents. (Unpublished master's thesis) Cukuova University, Social sciences Institute, Department of Educational Sciences, Adana, Turkey

[29] Korkmaz, N.H. (2007). The connection between summer sport schools and the self-esteem in children. Uludağ University, The J. Educational Faculty, xx (1): 49-65, Retrieved from; http://ucmaz.home.uludag.edu.tr/PDF/egiti $\mathrm{m} / \mathrm{htmpdf} / 2007-20(1) / \mathrm{M} 4 . \mathrm{pdf}$

[30] Kutanis, R.O., Tunc, T. (2013). The relationship between self-esteem and state-trait anxiety in nurses: a sample of a university hospital. "İş, Güç" Industrial Relations and Human Resources Journal. April, 15(2):1-15. DOI: 10.4026/1303-2860.2013.0222.x

[31] Mutlu, E., Duyan, V. (2012). The Socio-demographic characteristic, social support sources of the hemodialysis patients and effect of illness process on self-esteem. Ankara Sağlık Bilimleri Dergisi, 1(3): 1-38

[32] Ozcelik, I.Y., Imamoglu, O., Cekin, R., Baspınar, S.G. (2014). Üniversite Öğrencilerinin Yalnızlık düzeyleri üzerine sporun etkisi (Effect of sport on the level loneliness of the university student. Spor ve Performans Araştırmaları Dergisi, 6(1): 12-18. DOI No: 10.17155/spd.18840

[33] Ozogul, S.N. (1988). Effect to self-esteem of the child of mother's work and some individual qualities. Unpublished master's thesis, Hacettepe University, Ankara, Turkey.

[34] Piskin, M. (1996). Self-esteem, locus of control and academic achievement of secondary school children both in England and Turkey. Unpublished doctoral dissertation, University of Leicester, England.

[35] Rosenberg, M. (1965). Society and the adolescent: Self-image. Princeton: Princeton University Press, 30-31.

[36] Russell, D., Peplau, L.A., Cutrona, C.E. (1980). The Revised UCLA Loneliness Scale: Concurrent and Discriminate Validity Evidence. Journal of Personality and Social Psychology 39(3): 472-480. Retrieved from; http://www.peplaulab.ucla.edu/Peplau_Lab/Publications file s/Russel\%20Peplau\%20\%26\%20Cutrona\%2080.pdf

[37] Russell, D., Peplau, L. A., \& Ferguson, M. L. (1978). Developing the measure of loneliness. Journal of Personality assessment, 42(3): 290-294. http://fetzer.org/sites/default/file 
s/images/stories/pdf/selfmeasures/Self_Measures_for_Loneli ness_and_Interpersonal_Problems_UCLA_LONËLINESS.p df

[38] Softa, H.K., Karaahmetoglu, G.U., Demirci, U., Kilınc, E., Kandemir, A., Durak, B. (2015). An Analysis of the Level of Self-Respect and Loneliness Observed in the Senior Unıversity Students and the Influential Factors. Gümüşhane University Journal of Health Sciences 4(2): 227-243 Retrieved; http://sbd.gumushane.edu.tr/media/uploads/sbd/issues/cilt-4sayi-2/cilt4-sayi2.pdf

[39] Tremblay, M.S., Inman, J.W., and Willms, J.D. (2000). The relationship between physical activity, self-esteem, and academic achievement in 12-Year-Old Children. Pediatric Exercise Science, 12, 312-323. Retrieved from; http://extranet.nuorisuomi.fi/download/attachments/3245041 /the+relationship+between + physical+activity, self-esteem, $+\mathrm{a}$ nd+academic+achievement + in +12 -year-old+children.pdf

[40] Turan N, Tufan B (1987). Coopersmith self-esteem inventory (SEI) validity-reliability study. 23rd Nat. Congress of Psychiatry and Neurological Sciences. Istanbul, Turkey, 816-817.

[41] Uzuner, E.M., Karagun, E. (2014). rekreatif amaçlı spor yapan bireylerin yalnızlık düzeylerinin incelenmesi (Investigation of loneliness level of individuals who do recreational sports). Kocaeli University, Sosyal Bilimler
Dergisi, 27(1): 107-120. http://acikerisim.kocaeli.edu.tr:8080 /xmlui/bitstream/handle/11493/1524/Rekreatif\%20Ama\%C3 \%A71\%C4\%B1\%20Spor\%20Yapan\%20Bireylerin.pdf?sequ ence $=1 \&$ is Allowed $=\mathrm{y}$

[42] Walters, S.T., Martin, J.E. (2000). Does Aerobic Exercise Really Enhance Self-Esteem in Children? A Prospective Evaluation in 3rd - 5th Graders. Journal of Sport Behavior, March, 23(1): 1-10 Retrieved; http://www.cabdirect.org/abst racts/20001809584.html

[43] Whitehead, J.R., Corbin, C.B., Fox, K.R. (1997). The physical self: from motivation to well-being. (pp. 175-203). Champaign, IL, US: Human Kinetics, xiii, 329.

[44] Yanar, A., Erdogan, Z., Kayabası, N., Soylemezoglu, F. (2013). Giving handicraft training to the prisoners and the examination of the results. Atatürk University Sosyal Bilimler Enstitüsü Dergisi, 17 (1): 57-66. Retrieved; http://e-dergi.atauni.edu.tr/ataunisosbil/article/view/1020009 $346 / 1020007672$

[45] Young, J. E. (1982). Loneliness, depression and cognitive therapy: Theory and application. In L.A. Peplau \& D. Perlman (Eds.), Loneliness: A sourcebook of current theory, research and therapy (p.379-406). New York: Wiley

\footnotetext{
${ }^{\mathrm{i}}$ It was presented at the international conference on lifelong learning and leadership for all in Olomouc on October 29-31,2015.
} 